\title{
OPEN Fingerprinting molecular and isotopic biosignatures on different hydrothermal scenarios of Iceland, an acidic and sulfur-rich Mars analog
}

\author{
Laura Sánchez-García ${ }^{\bowtie}$, Daniel Carrizo, Antonio Molina, Victoria Muñoz-Iglesias, \\ María Ángeles Lezcano, Maite Fernández-Sampedro, Victor Parro \& Olga Prieto-Ballesteros
}

Detecting signs of potential extant/extinct life on Mars is challenging because the presence of organics on that planet is expected to be very low and most likely linked to radiation-protected refugia and/ or preservative strategies (e.g., organo-mineral complexes). With scarcity of organics, accounting for biomineralization and potential relationships between biomarkers, mineralogy, and geochemistry is key in the search for extraterrestrial life. Here we explored microbial fingerprints and their associated mineralogy in Icelandic hydrothermal systems analog to Mars (i.e., high sulfur content, or amorphous silica), to identify potentially habitable locations on that planet. The mineralogical assemblage of four hydrothermal substrates (hot springs biofilms, mud pots, and steaming and inactive fumaroles) was analyzed concerning the distribution of biomarkers. Molecular and isotopic composition of lipids revealed quantitative and compositional differences apparently impacted by surface geothermal alteration and environmental factors. $\mathrm{pH}$ and water showed an influence (i.e., greatest biomass in circumneutral settings with highest supply and turnover of water), whereas temperature conditioned the mineralogy that supported specific microbial metabolisms related with sulfur. Raman spectra suggested the possible coexistence of abiotic and biomediated sources of minerals (i.e., sulfur or hematite). These findings may help to interpret future Raman or GC-MS signals in forthcoming Martian missions.

The search for organic compounds is one of the main goals in planetary exploration. Because of its proximity to Earth, location within the habitability zone, and rock similarities with certain regions on Earth, Mars has been one of the key targets for searching for extraterrestrial life. It is thought that liquid water could have once made certain Martian areas inhabitable (e.g., ${ }^{1,2}$ ). In that case, simple life, such as bacteria or archaea, might have existed on the red planet and their remnants may still be present underneath the planet's frozen surface. Because of the complexity of accessing Mars environments and the limitations of accomplishing in-situ analysis there, the search for an extant or extinct subsurface biosphere on Mars has largely benefited from the use of extreme environments on Earth with analogies to Mars, as (partial) model systems for gathering certain information for future and ongoing Martian missions.

Amongst the extreme terrestrial environments with a resemblance to Mars, geothermal hot springs and the associated sinter precipitates are well known habitable environments on the early Earth (e.g., ${ }^{3,4}$ and references therein) that are considered potential analogs of hydrothermal processes on Mars (e.g., ${ }^{5-7}$ ). These environments, including impact-generated hydrothermal systems ${ }^{8,9}$, provide a localized source of heat, water, and the necessary materials to harbor life (e.g., ${ }^{7,10}$ ). A first step in the search for possible biosignatures on extraterrestrial hydrothermal systems is assessing the presence and state of organic matter. On Mars, the detection at Gale Crater of preserved organic molecules (i.e. thiophenic, aromatic and aliphatic compounds) by the SAM instrument onboard the MSL Curiosity ${ }^{11,12}$ fulfilled that first requirement. Then, investigating the occurrence and distribution of molecular biomarkers in terrestrial hydrothermal systems may give an insight into the fingerprints to seek in similar geothermal environments on Mars (i.e., former mud pots, fumaroles, geysers, or chimneys). 
Knowing what are the dominant microbial communities in these settings and how they distribute according to physicochemical variables (e.g., temperature, $\mathrm{pH}$, or redox conditions) is essential for interpreting possible biosignatures on analog sites on Mars.

Many mineral assemblages on Mars consisting of clays, sulfates, iron oxides, and hydrated silica have been identified through orbital and land-based observations. Some of these sites show geological and chemical correlation with hydrothermal alteration. Nili Patera, Elysium Planitia, Apollinaris Patera, as well as Gusev, Gale, and Jezero Craters are few examples of potential hydrothermal alteration associated with volcanic edifices (e.g., ${ }^{7,10,13}$ ). Gas-water-rock interactions were likely produced in fumaroles, mud pots, and hot springs by volatile sulfur ${ }^{14}$, altering the iron-rich basaltic Martian crust ${ }^{15}$. In the search for Martian life evidences, Jezero crater (landing site of the NASA's Perseverance rover in 2021) and Gusev crater (landing site of the NASA's Mars Exploration Rover Spirit in 2004) are particularly interesting targets due to the presence in both of amorphous silica, a mineral phase with high potential to preserve biosignatures on Earth that has been orbitaly identified in Jezero by the Compact Reconnaissance Imaging Spectrometer for Mars (CRISM) ${ }^{16}$ and in situ measured in Gusev by the Spirit rover ${ }^{17}$.

Iceland hydrothermal sites (e.g., Krýsuvík, Hveragerdi, or Námafjall), resulting from circulating water by magma plumes heating and formed in contact with high-Fe basalts ${ }^{18}$, are considered a natural laboratory for analog studies of Mars ${ }^{19}$, containing hot springs, geysers, mud pots, and steam vents ${ }^{20}$ with abundant opaline silica deposits and elemental sulfur as in Gusev Crater ${ }^{17}$. Astrobiological features on Iceland include the aforementioned hot springs and their associated microbial populations, including extremophilic life combining polar and hydrothermal systems. Space-related missions on Iceland go back to some 50 years, when NASA astronauts trained for the Apollo 11 moon landing on Icelandic soil" ${ }^{21}$. Now, various projects develop on this remote "Land of Fire and Ice" to understand habitability and environmental-microbial interactions with an eye on future astrobiological missions to Mars. Ecological studies have used DNA sequencing ${ }^{22,23}$ or lipid biomarkers analysis ${ }^{24,25}$ to determine the composition and community structure of hot springs microbial mats from geochemically diverse Icelandic geothermal fields, assessing in some cases the effect of physicochemical variables such as sulfide concentration, $\mathrm{pH}$ or temperature ${ }^{22}$. The discovery of hydrothermal deposits on Mars has also raised the interest in hydrothermal siliceous deposits on Iceland due to their capacity to preserve microbial biosignatures, with an eye on preparing future mission targeting potential biosignatures in analogous deposits on Mars ${ }^{26}$. While the search for microbial biosignatures on Icelandic hydrothermal deposits have focused on hot springs, other hydrothermal settings with higher relevance for the presently inactive hydrothermal Mars (e.g., fossilized fumaroles or mud pots) remain unexplored.

Here we wanted to move forward to explore the microbial fingerprint in geothermal substrates others than hot springs, with different mineral sequence and progressively lower availability of liquid water to simulate different scenarios with a potential analogy to hydrothermal Mars. We investigated three different geothermal fields along the Mid-Atlantic Ridge: Krýsuvik, located on the Reykjanes peninsula; Hveragerdi, to the southeast of the Hengill volcanic complex; and Námafjall, adjacent to Krafla volcano in northern Iceland (Fig. 1, see Methods section). These currently active hydrothermal areas show fluid-dominated mud pots and gas-driven fumaroles that, in combination with the meteoric cold water, produced a wide range of alteration products, like sulfates, sulfides, amorphous silica phases, clay minerals, and Fe-Ti oxides ${ }^{18,20}$. We explored the molecular and isotopic composition of lipid biomarkers in four hydrothermal substrates (hot springs, mud pots, active and inactive fumaroles). A total of 11 samples were analyzed for interpreting their biological signature and carbon metabolism (Fig. 1); three hot spring biofilms at $54^{\circ} \mathrm{C}$ (MAT-54), $70^{\circ} \mathrm{C}$ (MAT-70), and $78{ }^{\circ} \mathrm{C}$ (MAT-78), in Hveragerdi; two mud pots at $74^{\circ} \mathrm{C}$ (MP-74), in Námafjall, and $87^{\circ} \mathrm{C}$ (MP-87), in Krýsuvik; and soil samples from two active fumaroles at $25^{\circ} \mathrm{C}$ (AF-25) and $90^{\circ} \mathrm{C}$ (AF-90), in Krýsuvik, and four inactive fumaroles at $20^{\circ} \mathrm{C}$ (IF20), $49^{\circ} \mathrm{C}$ (IF-49), $66^{\circ} \mathrm{C}$ (IF-66), and $74^{\circ} \mathrm{C}$ (IF-74), in Námafjall. All samples showed pH values ranging from 1 to 6 (Table 1). The diversity and distribution of biomarkers in each regime were analyzed in relation to their mineralogy and variation of different physicochemical variables (temperature, $\mathrm{pH}$, water, or light accessibility) to understand their influence in determining quantitative or qualitative patterns. By fingerprinting the molecular and isotopic distribution patterns of lipid biomarkers in different hydrothermal scenarios, we aim at gathering as much knowledge as possible to constrain better (i) where to search for hypothetical biosignatures of past or present life on Mars and (ii) how to interpret them.

\section{Results and discussion}

Molecular and isotopic biosignatures in three Icelandic hot spring biofilms. The abundance and distribution of lipid biomarkers represent a mixture of contributions from all organisms present and past (when remnants are well preserved) in an environment ${ }^{27}$, providing insight on the overall community structure and biogeochemical processes occurring at a location (Text S1-S2). In the Hveragerdi hot springs, different lipid molecular patterns (Fig. S1) revealed contributions from diverse biological sources (see Text S3-S4). In MAT-54 and MAT-70, the relative abundance and isotopic composition of lipids (hydrocarbons, fatty acids, and hopanoids) diagnostic of cyanobacteria and other phototrophs (Text S1-S2) indicated a dominance of these microorganisms in their microbial community. This was consistent with previous descriptions of microbial mats in Hveragerdi hot springs collected from waters from 44 to $66^{\circ} \mathrm{C}^{24}$, where the thermophilic cyanobacterium Mastigocladus was dominant. Contribution from other phototrophs was deduced from the abundance (mostly in MAT-70) of lipid biomarkers of photosynthetic sulfur (Chlorobiaceae) and non-sulfur (Chloroflexi) bacteria (Fig. 2). Although specific biomarkers of Chloroflexi such as hentriacontatriene $\left(\mathrm{C}_{31: 3}\right)$ or HMW wax esters ${ }^{25}$ were not detected in this study, the presence of these green non-sulfur bacteria was considered likely due to different reasons. First, previous investigations on Hveragerdi reported the abundance of the Chloroflexus genus in different hot spring mats ${ }^{24,25}$, where it coexisted with cyanobacteria (mostly Mastigocladus), surrounding it for protection against sulfur and high temperatures, known to inhibit the cyanobacterium growth ${ }^{24,28}$. Second, the 

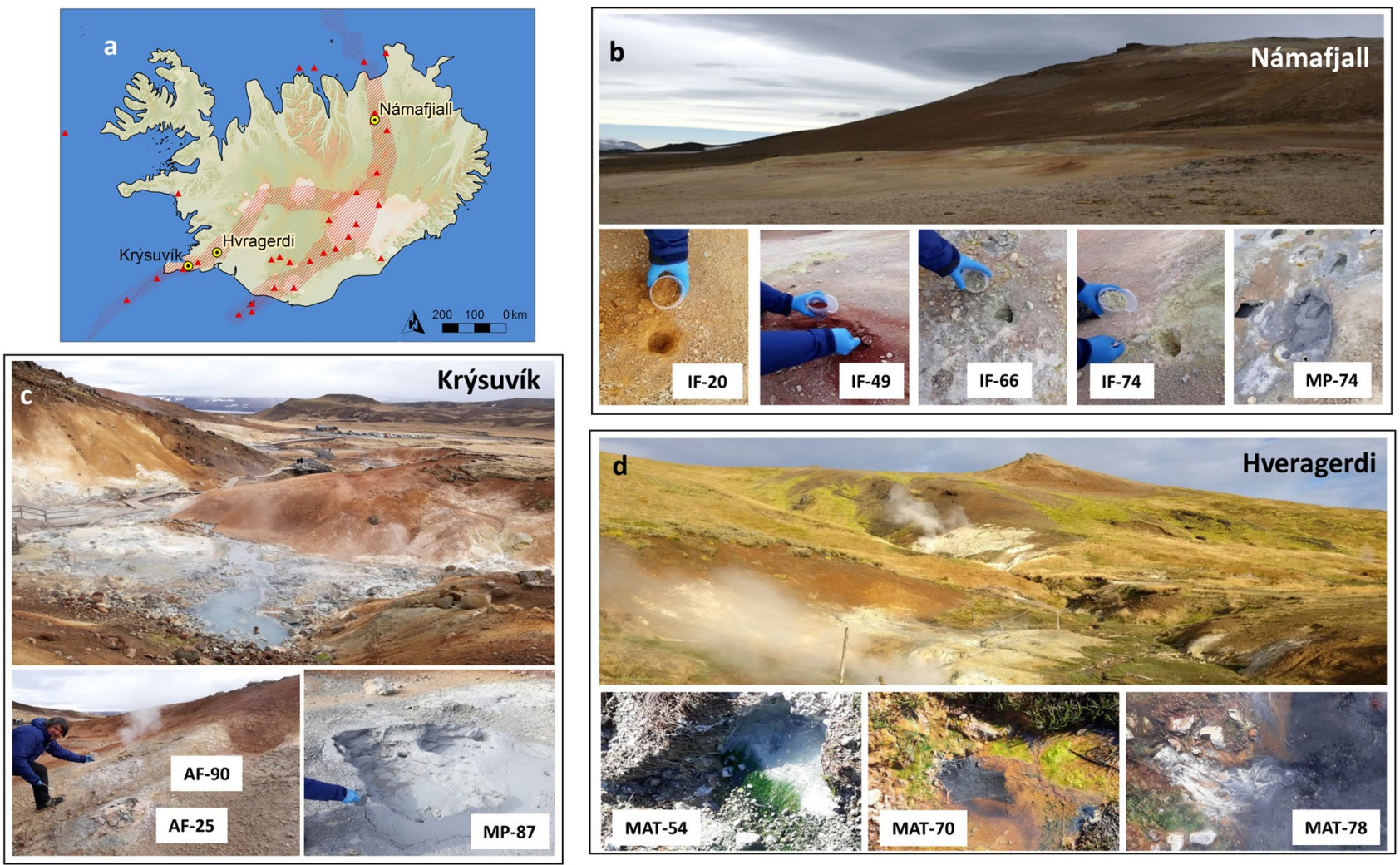

Figure 1. Icelandic geothermal areas investigated in this work (a) throughout the Mid-Atlantic Ridge (red dashed area with red triangles representing volcanoes) traversing the island; (b) Námafjall, (c) Krýsuvík, and (d) Hvragerdi. The map in (a) was built with ArcGIS Desktop 10.8 (https://desktop.arcgis.com/). Hydrothermal samples include four inactive fumaroles (IF) and one mud pot (MP) in Námafjall; two active fumaroles (AF) and one MP in Krýsuvík, and three hot spring biofilms (MAT) in Hveragerdi. The numbers in the sample names indicate the discrete temperature recorded in situ at the time of collection.

\begin{tabular}{|l|l|l|l|l|l|l|l|l|}
\hline Site & Sample & Latitude & Longitude & Temp. ${ }^{\circ} \mathbf{C}$ & $\mathbf{p H}$ & Water (\%) & System description & Sample description \\
\hline Hveragerdi & MAT-54 & $64^{\circ} 01^{\prime} 205$ & $21^{\circ} 23^{\prime} 657$ & 54 & 6 & 93 & Hot spring pot & $\begin{array}{l}\text { Dark green mat at the } \\
\text { pot side }\end{array}$ \\
\hline Hveragerdi & MAT-70 & $64^{\circ} 01^{\prime} 204$ & $21^{\circ} 23^{\prime} 690$ & 70 & 6 & 98 & Hot spring (boiling) & $\begin{array}{l}\text { Orange-pale green mat } \\
\text { at river side }\end{array}$ \\
\hline Hveragerdi & MAT-78 & $66^{\circ} 01^{\prime} 204$ & $21^{\circ} 23^{\prime} 690$ & 78 & 6 & 96 & Hot spring (boiling) & $\begin{array}{l}\text { Whitish fibers at river } \\
\text { side }\end{array}$ \\
\hline Námafjall & MP-74 & $63^{\circ} 53^{\prime} 359$ & $16^{\circ} 48^{\prime} 594$ & 74 & 2 & 82 & Dark grey mud pot & Dark grey mud \\
\hline Krýsuvík & MP-87 & $63^{\circ} 53^{\prime} 712$ & $22^{\circ} 03^{\prime} 316$ & 87 & 2 & 52 & Pale grey mud pot & Pale grey mud \\
\hline Krýsuvík & AF-25 & $63^{\circ} 53^{\prime} 709$ & $22^{\circ} 03^{\prime} 303$ & 25 & 2 & 57 & Cooler fumarole & $\begin{array}{l}\text { White-pale yellow solid } \\
\text { material }\end{array}$ \\
\hline Krýsuvík & AF-90 & $63^{\circ} 53^{\prime} 708$ & $22^{\circ} 03^{\prime} 302$ & 90 & 1 & 71 & Steaming fumarole & $\begin{array}{l}\text { White-pale yellow solid } \\
\text { material }\end{array}$ \\
\hline Námafjall & IF-20 & $63^{\circ} 38^{\prime} 392$ & $16^{\circ} 48^{\prime} 696$ & 20 & 3 & 0.04 & Non-steaming fumarole & Ochre soil substrate \\
\hline Námafjall & IF-49 & $63^{\circ} 38^{\prime} 392$ & $16^{\circ} 48^{\prime} 695$ & 49 & 3 & 0.02 & Non-steaming fumarole & Vermilion soil substrate \\
\hline Námafjall & IF-66 & $63^{\circ} 38^{\prime} 392$ & $16^{\circ} 48^{\prime} 697$ & 66 & 4 & 0.03 & Non-steaming fumarole & Grey soil substrate \\
\hline Námafjall & IF-74 & $63^{\circ} 38^{\prime} 392$ & $16^{\circ} 48^{\prime} 694$ & 74 & 1 & 0.02 & Non-steaming fumarole & Pale yellow soil substrate \\
\hline
\end{tabular}

Table 1. Location and description of the 11 hydrothermal samples in the four Icelandic regimes; hot spring biofilms (MATs), mud pots (MPs), active fumaroles (AFs), and inactive fumaroles (IFs). ${ }^{\mathrm{a}}$ Content of interstitial water gravimetrically determined by subtracting from the initial sample weight the constant mass reached after drying the sample at $50{ }^{\circ} \mathrm{C}$ in an oven for $48-72 \mathrm{~h}$. 

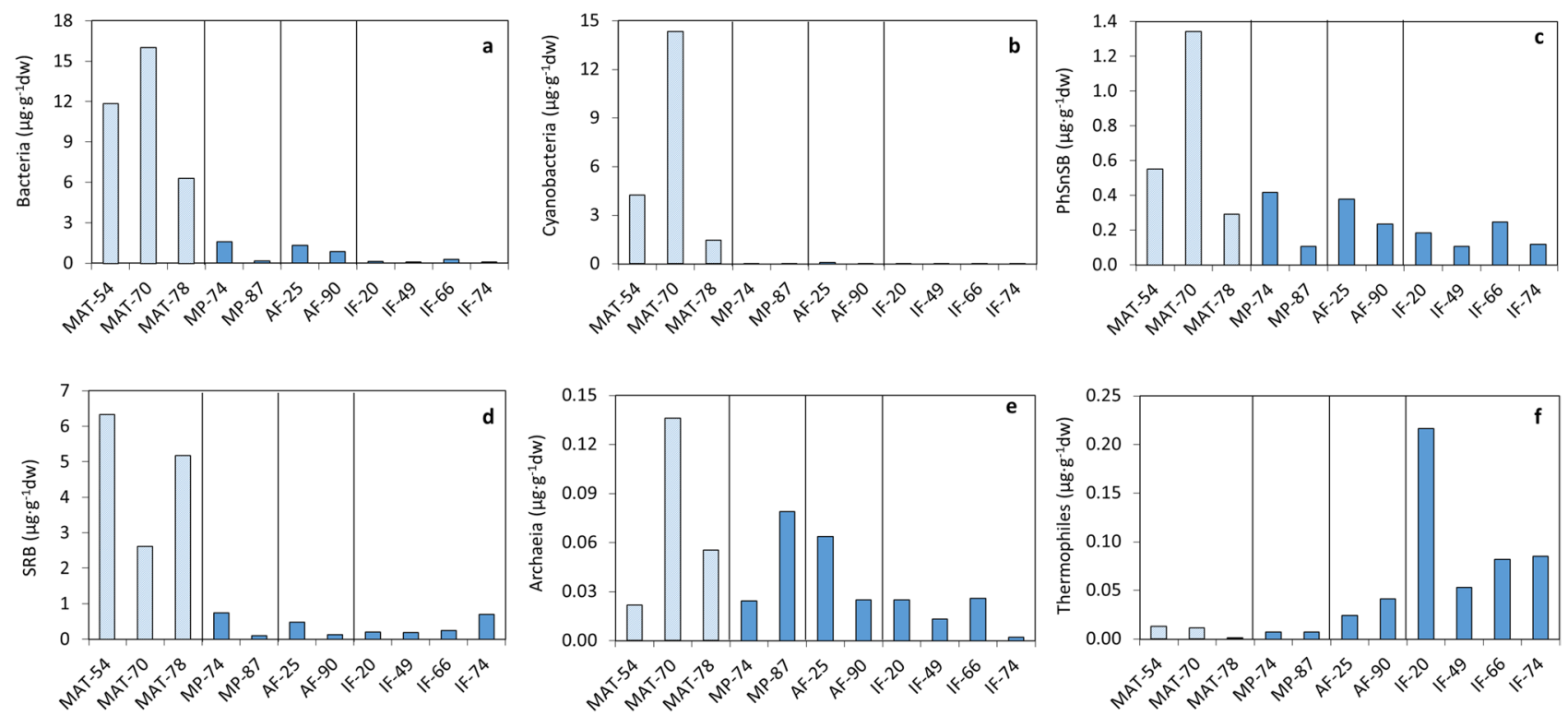

Figure 2. Relative contribution of microbial input sources to the samples biomass in the four hydrothermal regimes, inferred from the presence ( $\mu \mathrm{g} \cdot \mathrm{g}^{-1}$ of dry weight) of lipid biomarkers of (a) bacteria (sum of $n$-fatty acids from 16:0 to $18: 0 ;{ }^{58}$ ); (b) cyanobacteria (sum of $n$-heptadecane, isomeric $n$-heptadecenes, and

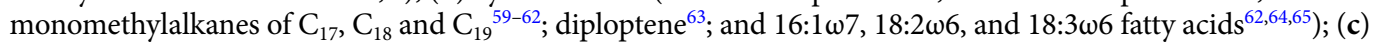
photosynthetic sulfur and non-sulfur bacteria or PhSnSB (sum of the $n$-alkanols $\mathrm{C}_{16}, \mathrm{C}_{17}$, and $\mathrm{C}_{18}{ }^{66}$ ); (d) sulfatereducing bacteria or SRB (sum of phytane ${ }^{67}$; i/a-pairs of 15:0, 17:0, and 15:1 fatty acids ${ }^{35}$; and 16:1 $\omega 5,17: 1$, and 18:1 $\omega 5$ fatty acids ${ }^{35,68,69}$ ); (e) archaea (squalane ${ }^{70,71}$ ); and (f) thermophiles (sum of dicarboxylic acids; ${ }^{72}$ ). See Text S1 for details on the uses and limitations of the approach.
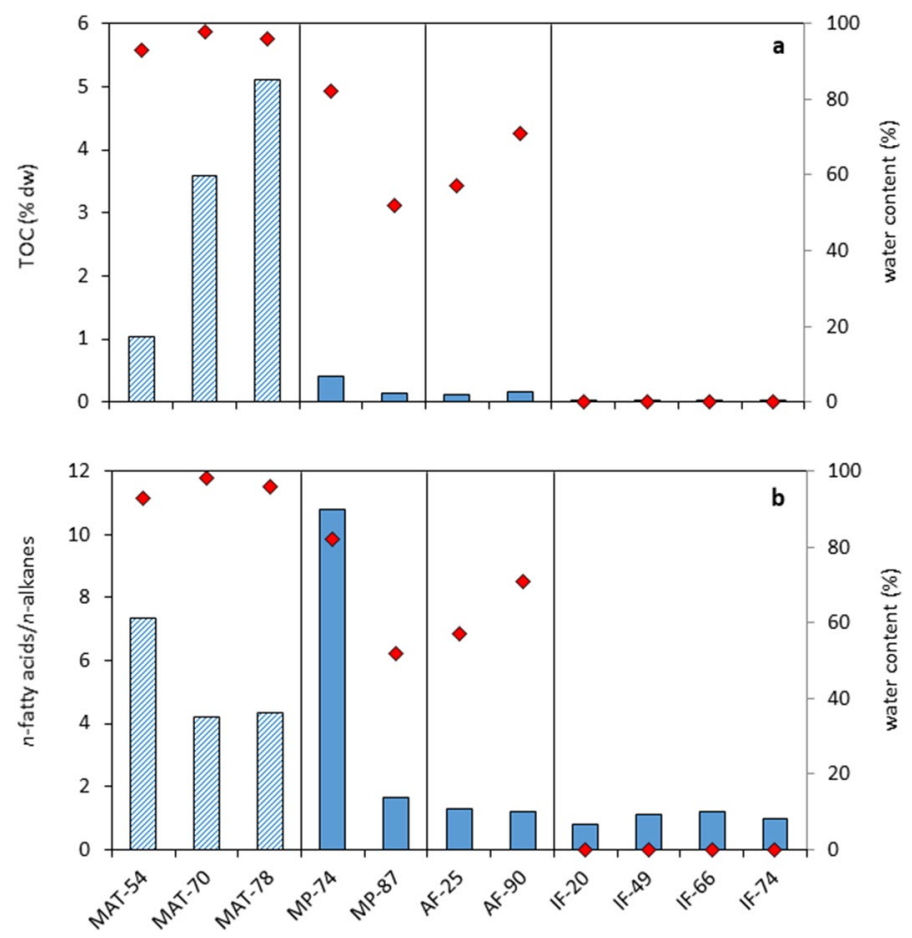

Figure 3. Estimate of (a) biomass and (b) biological activity degree (blue bars) relative to the sample water content (red diamonds) in the four hydrothermal substrates; hot spring biofilms (MATs), mud pots (MPs), active (AFs) and inactive (IFs) fumaroles. Total biomass is accounted for as the content of total organic carbon (TOC, $\%$ of dry weight). The extent of freshness or biological activity was assessed based on the relative abundance of functional groups (i.e. carboxylic acids) over saturated straight-chain (normal) alkanes (i.e. the $n$-fatty acids/ $n$-alkanes ratio) (see Text $\mathrm{S} 1$ ). 


\begin{tabular}{|c|c|c|c|c|c|c|c|}
\hline Sample & TOC $(\% \mathrm{dw})^{\mathrm{a}}$ & $\mathrm{TN}(\% \mathrm{dw})^{\mathrm{b}}$ & $\left.\delta^{13} \mathrm{C}(\%)\right)^{c}$ & $\delta^{15} \mathrm{Nv}(\%)^{d}$ & \begin{tabular}{|l} 
Total lipids $\left(\mu \mathrm{g} \cdot \mathrm{g}^{-1}\right.$ \\
$\mathrm{dw})^{\mathrm{e}}$
\end{tabular} & \begin{tabular}{|l|}
$n$-fatty acids $/ n$ - \\
alkanes $^{f}$
\end{tabular} & br- $\mathrm{C}_{17} / \mathrm{n}-\mathrm{C}_{17}{ }^{\mathrm{g}}$ \\
\hline MAT-54 & 1.03 & 0.18 & -18.2 & 0.59 & 27 & 7 & 0.069 \\
\hline MAT-70 & 3.59 & 0.45 & -17.9 & -0.87 & 105 & 4 & 0.28 \\
\hline MAT-78 & 5.12 & 0.88 & -20.8 & -5.4 & 17 & 4 & 0.11 \\
\hline MP-74 & 0.41 & 0.09 & -16.1 & -2.7 & 3.3 & 11 & 0.098 \\
\hline MP-87 & 0.14 & nd & -21.2 & nd & 0.62 & 1.6 & 2.4 \\
\hline AF-25 & \begin{tabular}{|l|}
0.11 \\
\end{tabular} & nd & -16.7 & nd & 3.9 & 1.3 & 0.11 \\
\hline AF-90 & 0.16 & nd & -8.1 & nd & 2.2 & 1.2 & 1.4 \\
\hline IF-20 & 0.02 & nd & -21.1 & nd & 1.2 & 0.80 & 0.60 \\
\hline IF-49 & 0.02 & nd & -20.2 & nd & \begin{tabular}{|l|}
0.88 \\
\end{tabular} & 1.1 & 0.10 \\
\hline IF-66 & 0.03 & nd & -10.0 & nd & 1.5 & 1.2 & 0.44 \\
\hline IF-74 & 0.01 & nd & -20.1 & nd & 1.3 & 0.99 & 0.14 \\
\hline
\end{tabular}

Table 2. Organic geochemical composition of the studied hydrothermal samples on Iceland. ${ }^{\text {a Total organic }}$ carbon (TOC). ${ }^{\mathrm{b}}$ Total nitrogen (TN). ${ }^{\mathrm{c} B u l k}$ stable carbon isotopic composition of TOC. ${ }^{\mathrm{d} B u l k}$ stable nitrogen

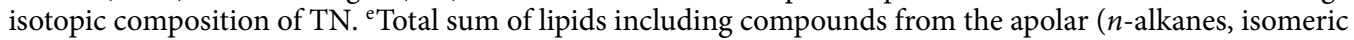
$n$-alkenes, isoprenoids), acid ( $n$-fatty acids, i/a-fatty acids, mono- and polyunsaturated fatty acids, and cyclopropyl fatty acids), and polar ( $n$-alkanols, phytol, and sterols) fractions (see Fig. S1, S3, S4 for details on

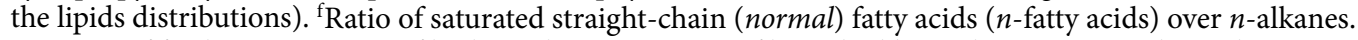
Estimate of freshness or extent of biological activity. ${ }^{\text {SSum }}$ of branched heptadecanes over $n$-heptadecane. Estimate of the relative abundance of heterotrophs ${ }^{57}$.

macroscopic aspect of our MAT-70 (Fig. 1d) coincided largely with that of Chloroflexus-rich biofilms (i.e., greenorange gelatinous and filamentous biomass) described by others ${ }^{24,25}$. Third, the slightly enriched compoundspecific and (mostly) bulk $\delta^{13} \mathrm{C}$ ratios observed in the three biofilms (Fig. S2) relative to $\delta^{13} \mathrm{C}$ signatures purely cyanobacterial (Text S2) (see next).

The bulk and molecular $\delta^{13} \mathrm{C}$ composition of MAT-54 and MAT-70 suggested that autotrophic carbon fixation in the two biofilms was mostly conducted through two major pathways (Text S4), consistent to a microbial community structure dominated by cyanobacteria (i.e., Calvin cycle) and Chloroflexus (i.e., 3-hydroxypropionate or $3 \mathrm{HP}$ bicycle). On the one hand, bulk $\delta^{13} \mathrm{C}$ in MAT-54 $(-18.2 \%$ ) and MAT-70 $(-17.9 \%$ ) (Table 2) denoted a slight depletion in ${ }^{13} \mathrm{C}$ relative to pure Chloroflexus mats $(-14.9 \%$ ) growing autotrophically (i.e., through the $3 \mathrm{HP}$ bicycle) in similar hot springs from Yellowstone National Park ${ }^{29}$. On the other hand, the wide range of values of compound-specific $\delta^{13} \mathrm{C}$ in both biofilms (i.e., from -18 to $-30 \%$; Fig. S2) covered values of carbon acquisition typical of users of the Calvin cycle (from -19 to $-30 \% 0^{30}$ and the $3 \mathrm{HP}$ bicycle (from -4 to $-15 \% 0^{31}$ ).

In MAT-78, in contrast, the presence of cyanobacteria and other phototrophs was considered a minority (Fig. 2), according to the distribution of lipid biomarkers observed in the sample (Fig. S1). The lower proportion of phototrophs was consistent with the higher temperature in this compared to the other two biofilms, which was over the upper-temperature limit of chlorophyll at $\sim 73{ }^{\circ} \mathrm{C}^{32}$. The microbial community in MAT-78 was instead dominated by biomarkers of sulfate-reducing bacteria or SRB (e.g., Firmicutes or $\delta$-Proteobacteria) (see Text S3). According to other ${ }^{22,23}$, the main primary producers in Icelandic hot springs at temperatures $>66{ }^{\circ} \mathrm{C}$ include representatives of the bacterial divisions Aquificales, Deinococcus-Thermus group, Thermodesulfobacterium group, Thermotogales, and Nitrospira group. In addition, some Proteobacteria ( $\gamma$ and $\beta$ classes) and Firmicutes (Bacilli) have also been reported in microbial mats from hot springs at $70 \pm 4{ }^{\circ} \mathrm{C}$ in Hveragerdi ${ }^{22,23}$. The relevant role of sulfur in this sample was supported by the aspect of MAT-78, where grey sulfur-rich deposits covered most of the mat filaments (Fig. 1d). The conditions in this site may be favorable for aerobic sulfur- and hydrogenoxidizing bacteria on top of the white sulfur-rich mat and for anaerobic sulfur and sulfate reducers in the dark grey undermass (Fig. 1d), as described in similar biofilms from Hveragerdi hot springs ${ }^{22}$.

According to this, the stable carbon isotopic composition of MAT-78 denoted meaningful participation of the reductive acetyl-CoA pathway for the autotrophic incorporation of carbon, with an additional potential contribution from the rTCA pathway (see Text S4). Overall, $\delta^{13} \mathrm{C}$ values in MAT-78 were generally more depleted in ${ }^{13} \mathrm{C}$ than those in the other biofilms (Fig. S2), both the bulk (i.e., $-20.8 \%$ ) and compound-specific ratios (from -19.1 to $-34.3 \%$ ). Carbon fixation pathways involving a large fractionation of ${ }^{13} \mathrm{C}$ that result in depleted $\delta^{13} \mathrm{C}$ signatures (i.e., more negative $\delta^{13} \mathrm{C}$ ) may be either the Calvin cycle or the reductive acetyl-CoA pathway (see Text S2). As the presence of phototrophs in MAT-78 was regarded as a minority due to its high temperature, the reductive acetyl-CoA pathway was considered the most plausible pathway to explain the relatively more negative values of $\delta^{13} \mathrm{C}$ in this biofilm, in detriment of the Calvin cycle. Microbial groups using the reductive acetyl-CoA pathway (see Text S2) that has been described in high-temperature hot spring mats in Hveragerdi are Firmicutes or $\delta$-Proteobacteria ${ }^{23}$. The presence of these microorganisms in MAT-78 would be consistent with the relatively higher abundance of iso/anteiso fatty acids diagnostic of gram-positive bacteria ${ }^{33}$ and $\mathrm{SRB}^{34,35}$ in this relative to the other two biofilms (Fig. S1). In addition, a certain contribution from other autotrophic carbon fixation pathways causing less fractionation than the reductive acetyl-CoA pathway (Text S2), such as the reductive tricarboxylic acid (rTCA), was also considered to explain the relative enrichment of the bulk $\delta^{13} \mathrm{C}$ relative to the lipids-specific $\delta^{13} \mathrm{C}$ values (Fig. S2). Aquificales or Nitrospira are some of the thermophile microorganisms 
described in Hveragerdi hot springs ${ }^{23}$ that may fix carbon using the rTCA pathway ${ }^{36}$, a metabolism producing bulk $\delta^{13} \mathrm{C}$ values from -12 to $-21 \% .^{30}$

Molecular and isotopic biosignatures in other Icelandic hydrothermal substrates; mud pots and fumaroles. The microbial diversity in hot spring mats has been previously assessed on Iceland, based on $\mathrm{DNA}^{22,23}$ and lipid biomarkers ${ }^{24,25}$, whereas that of other hydrothermal substrates with astrobiological relevance such as sulfur-rich and pyroclastic soils remain unexplored. Here, we investigated the molecular and isotopic composition of lipid biomarkers in samples of active geothermal regimes such as mud pots, active and inactive fumaroles to assess biological fingerprints in scenarios with analogies to Mars (e.g. Gusev Crater).

The observed molecular distribution patterns in the mud pots (Fig. S3) and fumaroles (Fig. S4-S5) differed largely from those in the three hot spring biofilms (Fig. S1), revealing a relatively higher contribution of archaea and thermophiles in the former, in detriment of cyanobacteria and other phototrophs (see Text S5). Among regimes, the proportion of bacteria, archaea, $\mathrm{SRB}$, and photosynthetic sulfur and non-sulfur bacteria $(\mathrm{PhSnSB})$ was generally higher in the MPs and AFs, whereas thermophiles were relatively more abundant in the active and (mostly) inactive fumaroles (Fig. 2). The signal of heterotrophs (i.e., br- $\mathrm{C}_{17} / n-\mathrm{C}_{17}$ ratio; see Text $\mathrm{S} 1$ ) was greatest in MP-87 and AF-90 (Table 2), which could be related to the presence of heterotrophic members of Nitrospira, Crenarchaeota, or Thermodesulfobacterium, as well as fermentative bacteria (Thermotogales), described in Hveragerdi (i.e., ${ }^{22}$ ).

Wide ranges of stable carbon isotopic ratios in the mud pot (Fig. S6) and fumarole (Fig. S7) samples supported the contribution of the mentioned different biosources, with the participation of various autotrophic carbon fixation pathways involving large and small fractionations of ${ }^{13} \mathrm{C}$ (see Text $\mathrm{S} 6$ ). In the mud pots, primary production appeared to be largely represented by the reductive acetyl-CoA pathway (mostly in MP-87), and a lower proportion of the Calvin cycle (mostly in MP-74). Carbon fixation through these pathways could be attributed to microorganisms previously described on Iceland hydrothermal regimes ${ }^{23}$, such as members of $\gamma$ - or $\beta$-Proteobacteria, in the case of the Calvin cycle ${ }^{36}$, or to members of Euryarchaeota (methanogenesis), Archaeoglobales (sulfate reduction) or $\delta$-Proteobacteria (sulfate reduction) in the case of the reductive acetylCoA pathway ${ }^{36}$. Additional contributions from the rTCA or $3 \mathrm{HP}$ pathways were also considered to explain the relatively enriched bulk $\delta^{13} \mathrm{C}$ in MP-87 $(-21.2 \%$ ) and mostly MP-74 (i.e., $-16.1 \%$ ). These alternative routes could have been conducted by thermophilic Aquificales (rTCA) and, only in the case of the cooler MP-74, by PhSnSB (i.e., Chlorobiaceae and Chloroflexi) respectively using the rTCA and 3HP pathways (Text S6). Similar participation of mixed carbon fixation pathways was deduced in the fumarolic substrates, with the reductive acetyl-CoA pathway (archaea and/or SRB) appearing to be dominant in the active systems, and the rTCA pathway playing a relevant role in the inactive fumaroles, likely due to the greatest presence of thermophiles (e.g., Aquificales, Nitrospira, or Chlorobiaceae) in this regime (Fig. 2f).

The compositional differences between the Icelandic mud pots and fumaroles relative to the hot spring biofilms was illustrated by the distribution of samples in three groups (i.e., MAT-54 and MAT-78; MAT-70; and rest of samples) in a diagram of Principal Components Analysis (PCA) (Text S8). While the samples showing the lowest biomass (i.e., mud pots and fumaroles) clustered together and showed a negative relationship with TOC, the three hot spring biofilms with relatively higher biomass plotted oppositely in the PCA diagram and grouped in two different clusters based on their different microbial composition (Fig. S8). Such differences were related to the abundance of either SRB (MAT-54 and MAT-78), or cyanobacteria, PhSnSB, and archaea (MAT-70) (Fig. 2). In contrast, mud pots and fumaroles were rather associated with thermophiles and $\delta^{13} \mathrm{C}$. In terms of metabolism, samples AF-90 and IF-66 showed similarities (Fig. S8) likely associated to a relatively higher incorporation of inorganic carbon through the $3 \mathrm{HP}$ and/or TCA pathways (Text S7).

Influence of environmental variables on the biological fingerprint on Icelandic geothermal environments analog to Mars. The biological fingerprint in the Icelandic geothermal substrates was analyzed in relation to a number of environmental variables (water content, $\mathrm{pH}$, and temperature) to understand their influence on the microbial composition (see Text 88 for details).

Water and $\mathrm{pH}$ resulted the variables influencing most the total amount of biomass and its microbial composition in the Icelandic hydrothermal samples according to a Redundancy Analysis (RDA) (Fig. 4). Both environmental variables showed positive correlation with TOC and the microbial biomarkers of bacteria, cyanobacteria, $\mathrm{SRB}, \mathrm{PhSnSB}$, and archaea (Fig. 4). The contribution of microorganisms sensitive to low $\mathrm{pH}$ values such as cyanobacteria ${ }^{37}$ to the total biomass was essential in the three biofilms, mostly MAT-70 (Fig. 2b). In the range of values considered here (i.e., from 1 to 6 ), the greatest biomass was thus produced in settings with circumneutral $\mathrm{pH}$ and highest supply and turnover of water (i.e., continuously renewed running water; Text S8).

In contrast to water and $\mathrm{pH}$, temperature did not seem such a determining variable in most of the organic variables attending to the RDA (Text S8). Only thermophiles showed a negative correlation with temperature, and plotted together with the low-temperature fumaroles (Fig. 4). Still, despite the low relationship between temperature and most of the biomarkers, a few patterns could be identified. For instance, the signals of bacteria, SRB, or PhSnSB were generally stronger at temperatures of $66-70^{\circ} \mathrm{C}$ (Fig. 2). For cyanobacteria, the general variation with temperature could not be detected, as the growth of these microorganisms was anyway negligible in other substrates than biofilms due to their low $\mathrm{pH}^{37}$. Still, in the samples where cyanobacteria were well detected (i.e., the three biofilms; Fig. 2b), their abundance decreased considerably at temperatures above $70^{\circ} \mathrm{C}^{32}$. Interestingly, the strongest signal of thermophile biomarkers was found in one of the virtually dry samples (inactive fumaroles) with the lowest temperature (i.e., IF-20; Fig. 2f). This apparent anomaly was hypothesized to be related to the characteristic episodic nature of thermal activity in hydrothermal systems such as fumaroles (see text S8), where the continuous variability of temperature with tim ${ }^{38,39}$ allows the alternation in time of microbial communities 


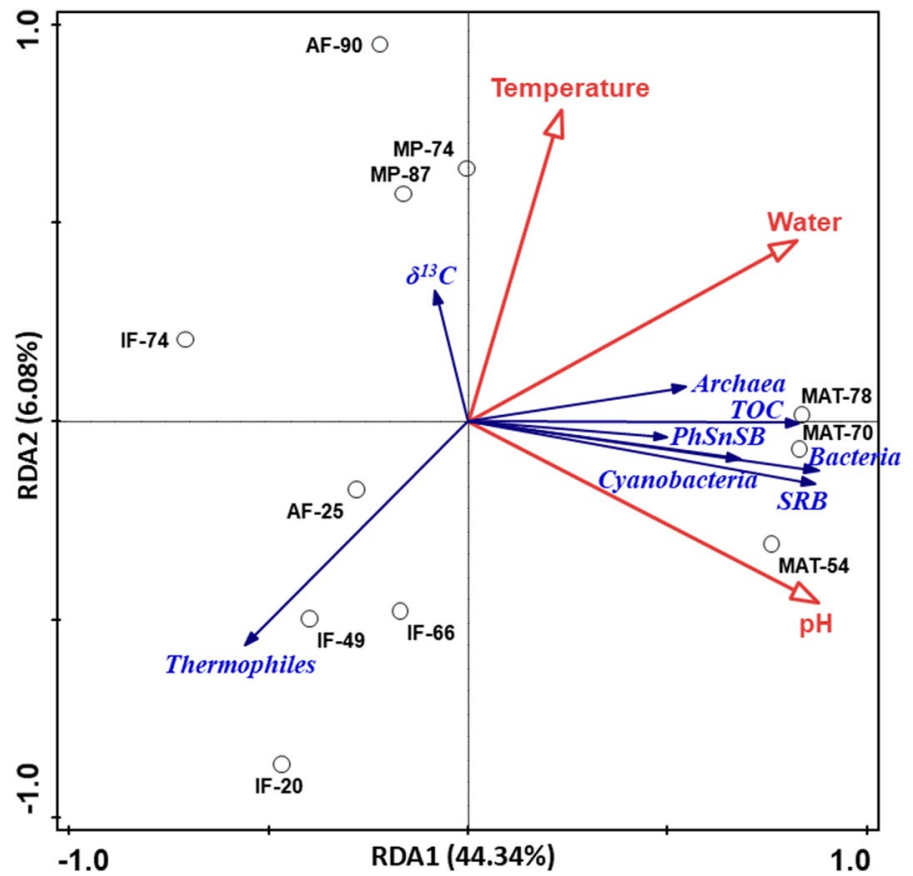

Figure 4. Ordination plot of Redundancy Analysis (RDA) on the Icelandic hydrothermal samples. The blue vectors represent the nine compositional variables tested (see Fig. S8) and the red vectors represent the environmental variables selected for assessing the influence on the organic composition; $\mathrm{pH}$, water, and temperature. See Fig. 1 for description on the samples naming. The axis RDA1 and RDA2 explained together $50.42 \%$ of the compositional variability of the samples.

\begin{tabular}{|c|c|c|c|c|c|c|c|c|c|c|}
\hline Sample & Anatase & Sulfur & Pyrite & Quartz & Hematite & Natroalunite & Kaolinite & Montmorillonite & Heulandite & $\begin{array}{l}\text { Amorphous } \\
\text { silica }\end{array}$ \\
\hline MAT-54 & & & & & & & & + & + & \\
\hline \multicolumn{11}{|l|}{ MAT-70 } \\
\hline MAT-78 & & + & + & & & & & & & \\
\hline MP-74 & + & + & + & & & & + & & & + \\
\hline MP-87 & & + & + & & & & + & & & \\
\hline AF-25 & + & & & & & + & + & & & + \\
\hline AF-90 & + & + & & & & & & & & + \\
\hline IF-20 & + & & & + & & & & & & \\
\hline IF-49 & + & & & & + & & & & & \\
\hline IF-66 & & + & & & & & & & & + \\
\hline IF-74 & + & + & & & & & & & & + \\
\hline
\end{tabular}

Table 3. Mineral composition of the eleven Icelandic hydrothermal samples (biofilms or MATs, mud pots or MPs, active fumaroles or AFs, and inactive fumaroles or IFs), with presence/absence notation, based on X-Ray Diffraction and Fourier Transform Infrared Spectroscopy.

with different tolerance to temperature ${ }^{40}$. The temporal variation of microbial populations with temperature imprints the substrate with biosignatures of both present and past communities ${ }^{39,41}$. Thus, the highest detection of thermophile biomarkers in IF-20 was considered to be likely recording a larger presence of thermophiles in the past, when a much higher temperature than that measured during the study sampling surely took place.

In sum, water and $\mathrm{pH}$ were the environmental factors affecting most (i) the total biomass (quantitative level), and (ii) the microbial community structure (qualitative level) in the Icelandic hydrothermal substrates, whereas temperature appeared to influence only the distribution of thermophiles.

Interpreting the biological fingerprint of the Icelandic hydrothermal regimes in a mineralogical context. The mineralogy of the hydrothermal substrates incorporating the biomarkers was also characterized. Overall, minerals containing sulfur and titanium oxide were measured by XRD and Raman to be ubiquitous in the samples (Table 3 and Fig. 5), while other minerals (hematite, pyrite, natroalunite, or clays) were only present in specific samples (Text S9). The presence of amorphous silica suggested by XRD curve profiles in 


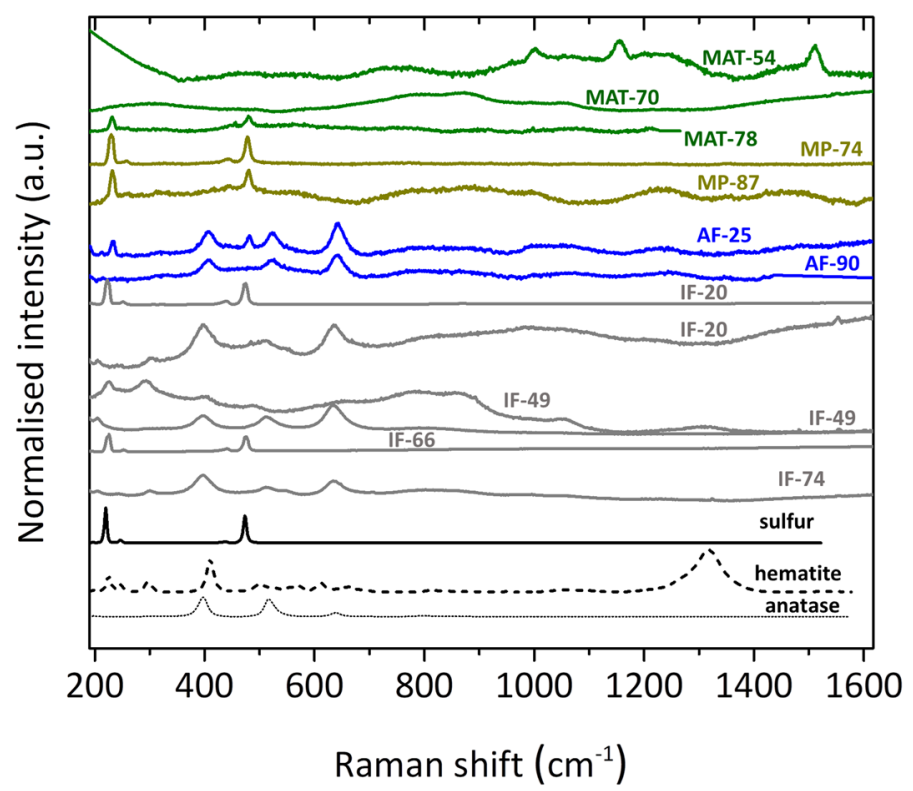

Figure 5. Raman spectra of the minerals identified in the Icelandic hydrothermal regimes; hot spring biofilms (MATs; green), mud pots (MPs; brown), active fumaroles (AFs; blue), and inactive fumaroles (IFs; grey). At the bottom, Raman spectra of minerals from the RRUFF database are shown in black for comparison and initial mineral identification. The spectrum of MAT-54 corresponds to carotenoids, according to Gall et al. ${ }^{73}$. Different Raman spectra profiles depending on the spot measured in IF-20 and IF- 49 are caused by mineral heterogeneities.

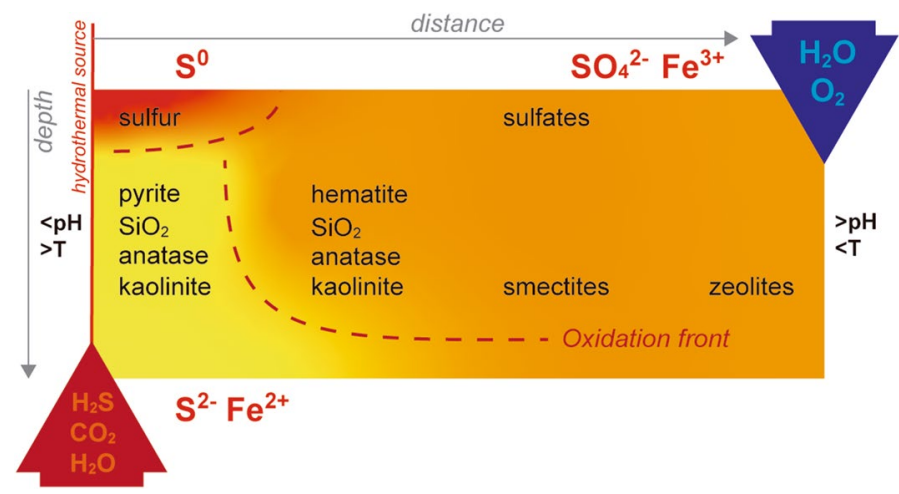

Figure 6. A simplified conceptual model of hydrothermal transect, showing the mineral distribution caused by hydrothermal alteration of original basaltic rocks at surface of the studied Iceland sites. Surface mineralogy is constrained by acid leaching and their exposure to oxidizing conditions, which depends on the physicochemical properties of hydrothermal (red arrow) and meteoric (blue arrow) fluids. Oxidation front (red dashed line) indicates the oxidation of sulfides and elemental sulfur into sulfates ${ }^{20}$.

some samples (Table 3) was supported by Fourier Transform Infrared (FTIR) spectroscopy in the near infrared (Text S9; Fig. S9). Sample alteration minerals are function of the local temperature (Fig. S10), redox conditions, and fluid acidity that permits mobilization of ions at acidic hot conditions (see Fig. S10). Mineralogy characterization revealed that phases rich in sulfur (pyrite or elemental sulfur) or titanium (anatase) dominated at samples with temperatures $\geq 66^{\circ} \mathrm{C}$. In contrast, other alteration phases such as hematite, sulfates (natroalunite), clays (kaolinite, montmorillonite), or zeolites (heulandite) were progressively more abundant as hydrothermal activity and temperature decreased (Table 3; Fig. 5).

The mineral sequence in these Icelandic substrates (Table 3 ) fits well with the mineralogical and geochemical trends produced in halos of geothermal surface alteration around mud pots and fumaroles ${ }^{20}$. Hydrothermal acidsulfate alteration is a result of the interaction between aqueous $\mathrm{H}+$ and primary minerals (Fig. 6). The localized volcanic-derived high-temperature fluids enriched in $\mathrm{H}_{2} \mathrm{~S}$ and $\mathrm{CO}_{2}$ produce extensive pyrite and native sulfur deposits (as found in samples MAT-78, MP-74, MP-87, IF-66, and IF-74). When they show low water-rock ratios conditions, they are considered gas fumaroles, while those with high water-rock ratios result in hot springs and mud pots. In the fumaroles, secondary minerals are generated from the volcanic vapors or during alteration of 
primary substrate, while in the mud pots they are controlled by the oxidation of iron sulfide deposits. The leaching dominates closest to the discharge source, resulting in significant cation mobilization, depletion of most major elements, and enrichment in $\mathrm{SiO}_{2}$ (e.g., amorphous phase or quartz) and $\mathrm{TiO}_{2}$ (e.g., anatase) (Fig. 6). Secondary iron and sulfur mineral assemblages are produced by their position along the oxidation front. In this way, sulfate-bearing solutions form sulfates such as natroalunite (as in AF-25) or iron-rich sulfates that breaks down to form hematite (as in IF-49). Smectite clays and zeolites are found in the distal margins of surface activity (as in MAT-54). This was supported by Raman spectra with peaks denoting alteration of minerals (e.g., native sulfur or hematite) primarily related to hydrothermalism (see Text S9).

Raman spectroscopy provided additional details about the formation conditions and potential biogenic origin of some mineral phases, besides detecting photosynthesis-related biomolecules (i.e., carotenoids) in MAT-54 (Text S9). For instance, in the identification of hematite in IF-49, the structural disorder suggested by the broad band around $800 \mathrm{~cm}^{-1}$ (Fig. 5) was interpreted to be potentially caused by both hydrothermalism or microbial intervention $^{42}$ (see Text S9). In addition, the detection of certain allotropes of native sulfur combined with results from the other techniques used here, allowed constraining bioformation conditions ${ }^{43,44}$ in some samples (see Text S9). The coexistence of different allotropes of native sulfur was deduced from the position of its characteristic Raman peaks in the samples (Fig. $5{ }^{45}$ ). The $\alpha$-sulfur allotrope mainly characterized by the Raman shifts around 220 and $473 \mathrm{~cm}^{-1}$ - caused by the vibration of the internal modes of the $\mathrm{S}_{8}$ ring $^{46}$ - was observed to be dominant in lower-temperature samples such as IF-20 or IF-49 (Fig. 5). In contrast, Raman blueshifts of about $10 \mathrm{~cm}^{-1}$ related to the $\gamma$-sulfur allotrope were observed in higher-temperature samples such as MAT-78 and MP-87, from which a potential biomineralization source cannot be discarded ${ }^{44}$. In MAT-78, the substantial presence of SRB biomarkers (Fig. 2d) was consistent with a relative production of sulfur upon sulfate reduction that supports the idea that the sulfur cycle is essential in this system and is likely the main source of primary productivity in this biofilm.

Altogether, temperature played a role in conditioning the mineralogy that supports specific microbial metabolisms indirectly through the surface geothermal activity (i.e., in general, temperatures $\leq 70{ }^{\circ} \mathrm{C}$ revealed more alteration signs of the original basaltic petrology, and greater abundance of phototrophs and SRB biomarkers). Moreover, the generally sulfur-rich mineralogy of the substrates (mostly those at high temperature) and the abundance of biomarkers associated with microorganisms utilizing sulfur for their growth (e.g., SRB or green sulfur bacteria) revealed the importance of the sulfur cycle in the primary productivity of the Icelandic hydrothermal regimes.

\section{Conclusions}

This work investigates mineralogical, molecular, and isotopic biosignatures on hydrothermal substrates from four regimes (hot spring biofilms, mud pots, active steaming fumaroles, and inactive fumaroles) to advance knowledge for the future search of molecular remnants on analogous Martian substrates. Whereas the study of the microbial ecology of hot spring biofilms has been previously addressed on Iceland, this is the first time that other hydrothermal substrates are investigated for their biomarkers fingerprints.

A direct comparison between Iceland and Martian hydrothermal systems is unachievable. Even when similar processes may have occurred, there are essential differences in water abundance, fluid chemistry, and atmospheric composition. This means that, for example, on Mars, soluble phases should be better preserved due to the lack of meteoric fluids (precipitation or other forms of surface water) whereas less preserved due to the intense irradiation on the Martian surface, and the dominant silica phase would be opal-A due to colder and drier conditions ${ }^{47}$. These opal-A rich deposits were found in Gusev crater by the Spirit Rover, whose wheel also exposed abundant sulfate minerals below the surface dust $\left({ }^{48}\right.$ and references therein), evidencing that these assemblages could be more widespread than previously thought. These deposits have even been associated with a fumarolic environment near the flanks of a volcano ${ }^{10}$, comparable to the Icelandic analog sites studied here, where amorphous silica was also detected.

Hydrothermal Iceland environments provide an interesting scenario to investigate habitability and biomarkers preservation for different reasons. First, the low complexity of the hydrothermal ecosystem on Iceland ${ }^{24}$ facilitates the interpretation of biosignatures associable with a few groups of microorganisms. Hot springs have even been singled out as one of the most favorable sites for the emergence of protocell ${ }^{49}$. Second, Icelandic landscapes combine a duality of glacial and volcanic features that offer a unique scenario to study habitability and adaptability to harsh environmental conditions. Third, all these features and the silica- and sulfur-rich mineralogy of the hydrothermal substrates convert Iceland on an accessible system to study biosignatures for its connections to Mars.

Molecular and isotopic distributions of lipids revealed compositional differences between the samples more or less influenced by mineralogical and geochemical factors (water supply and turnover, temperature, and $\mathrm{pH}$ ). Overall, the results denoted the importance of the sulfur cycle in the hydrothermal substrates, representing an essential contribution to the primary production in these regimes. Besides, Raman spectral differences between samples suggested the possible coexistence of abiotic and biomediated sources of minerals (i.e., sulfur or hematite) in the Icelandic hydrothermal systems. Accounting for biomineralization is a major interest in the search of life on extraterrestrial substrates, where the scarcity of organics certainly hampers the detection of molecular (organic) biomarkers.

We seek mineralogical signatures associated with hydrothermal systems to identify potentially habitable locations on Mars. The findings of this study go further and shed light on the search of biosignatures on these geothermal systems with interest for its analogy to Mars (i.e., high sulfur content, hydrothermalism, or silica), providing insights about the best mineralogical assemblages for hosting biomarkers in sulfur- or silica-rich substrates. Our detection of lipids biomarkers, pigments, and potentially biomediated minerals by instruments 
(GC-MS and Raman spectroscopy) similar to those carried onboard the Perseverance (Raman spectroscopy Supercam) and Rosalind Franklin (Mars Organic Molecule Analyser and Raman Laser Spectrometer) rovers contributes to constrain the mineral context where biosignatures could be found in analogous scenarios on Mars (e.g., Gusev or Jezero craters). Understanding the relationship between biosignatures and inorganic variables such as mineralogy, temperature, redox state, or $\mathrm{pH}$ is vital for interpreting future Raman or GC-MS signals in the forthcoming Mars2020 (NASA) and ExoMars (ESA) missions to Mars, where the presence of organics is expected to be very low.

\section{Methods}

Study area. This study was conducted in three geothermal regions of Iceland distributed along the MidAtlantic Ridge; Krýsuvík, Hveragerdi (a.k.a. Hengill), and Námafjall (Fig. 1). On the north of Iceland, Námafjall is a high-temperature geothermal field (T above $200^{\circ} \mathrm{C}$ at $1000 \mathrm{~m}$ depth) with a landscape defined by the homonymous hill and the abundant fumaroles, mud pots and hot springs (Fig. 1b) spread all over the base, slope and summit ${ }^{21}$, with abundant sulfur deposits. The hills substrate is primarily composed of basaltic hyaloclastite. Still, fumaroles in Námafjall are in contact with iron-enriched basalts at its bases. On the Reykjanes Peninsula (SW Iceland), the volcanic system of Krýsuvík is a basaltic territory made up of post-glacial lava fields, ridges of pillow lavas, and hyaloclastites ${ }^{20}$. The high-temperature geothermal area of Krýsuvík extends over $40-60 \mathrm{~km}^{2}$ and consists mainly of acid surface alteration and hot ground, steam vents, and steam-heated hot springs and mud pots (Fig. 1c). The surface geothermal activity in Krýsuvík affects its mineralogy strongly, with alteration mineral sequences varying from amorphous silica, anatase, pyrite, and native sulphur in areas of high activity (active steam vents and mud pots), to kaolinite and iron oxyhydroxides and oxides in areas of medium geothermal activity (hot grounds), and to montmorillonite on the margins of the surface geothermal activity ${ }^{20}$. Some $50 \mathrm{~km}$ northeastward, the Hveragerdi geothermal region (Fig. 1d) is in direct connection with the active Hengill volcano by fissures swarms ${ }^{50}$. Rocks in this area are composed of subglacially formed hyaloclastite and interglacial basalt from lava flows, whereas montmorillonite is the dominant alteration clay mineral at shallow depths. In Hveragerdi, geothermal waters are dominated by low salinity (mostly meteoric water), high sulphide concentration, high temperature, and alkaline $\mathrm{pH}^{22,23}$, although hydrothermal fluid from acidic to neutral $\mathrm{pH}$ (from 2.5 to 6.6) have also been reported ${ }^{51}$. Microbial mats in the sulphidic hot springs at Hveragerdi have been described to contain low species diversity compared to other hydrothermal regions ${ }^{24}$.

Samples. In April 2018, a field campaign funded by the Europlanet Project was conducted to collect 11 samples of different hydrothermal substrates (biofilms, mud pots, and fumaroles) from three geothermal scenarios on Iceland (Fig. 1). In Námafjall, samples of mud and hot ground were collected from a grey mud pot at $74{ }^{\circ} \mathrm{C}$ (MP-74) and four inactive (i.e. non-steaming and with water contents $\leq 0.04 \%$ ) fumaroles (IF) at temperatures ranging from $20^{\circ}$ to $74^{\circ} \mathrm{C}$ (Table 1), displaying different color (ochre, red, grey and pale yellow; respectively) (Fig. 1b). In Krýsuvík, a second mud sample was taken from another grey mud pot at $87^{\circ} \mathrm{C}(\mathrm{MP}-87)$ and two samples of hot ground from two active (i.e., steaming and with water contents $\geq 50 \%$ ) fumaroles (AF) at $25^{\circ}$ and $90^{\circ} \mathrm{C}$ (Fig. 1c). In Hveragerdi, three biofilms or microbial mats (MAT) of different aspect (dark green, orange and light green, and light grey) were sampled at sites recording in-situ water temperatures of $54{ }^{\circ} \mathrm{C}$ (MAT-54), $70{ }^{\circ} \mathrm{C}$ (MAT-70), and $78^{\circ} \mathrm{C}$ (MAT-78), respectively (Fig. 1d). The $\mathrm{pH}$ of all samples was measured in situ, and its values ranged from 1 to 2 in the MP and AF samples, from 1 to 4 in the IFs, and were 6 in the three MAT samples (Table 1). All samples were grabbed with solvent clean (methanol or $\mathrm{MeOH}$ and dichloromethane or DCM) stainless-steel spatula. They were all stored in solvent-cleaned (DCM and $\mathrm{MeOH}$ ) polypropylene containers at $-20^{\circ} \mathrm{C}$ and subsequently lyophilized. Before biogeochemical analysis, all samples were grounded in a pestle.

X-ray diffraction (XRD), Fourier transform infrared spectroscopy (FTIR), and Raman spectroscopy. The mineralogical composition of the samples was determined by the combination of XRD and Raman spectroscopy. XRD was conducted using a Bruker X-Ray diffractometer (AXS D8-Focus), scanning samples in the $2 \Theta$-diffraction angle from $5^{\circ}$ to $70^{\circ}$, with a scanning step size of $0.01^{\circ}$, at $40 \mathrm{kV}$ and $40 \mathrm{~mA}$ with a Cu X-ray source ( $\mathrm{Cu} \mathrm{Ka1,2,} \lambda=1.54056 \AA$ ). Near Infrared (NIR; from 10,000 to 4,000 $\mathrm{cm}^{-1}$ ) spectra were collected at $4 \mathrm{~cm}^{-1}$ resolution with a Nicolet iS50FTIR spectrometer using the diffuse reflection (DRIFTS) attachment, a DTGS-KBr detector, and a XT-KBr beamsplitter. Raman spectroscopy was performed with a Horiba Jobin Yvon Hri550 connected to a Charge Coupled Device (CCD) with $1024 \times 256$ pixels cooled to $203 \mathrm{~K}$ for thermal-noise reduction. Before work, the Raman spectrometer was prepared with four diffraction gratings of $600,1200,1800$ and 2400 grooves/mm that provide a wide range of intensity signal/resolution ratio. Sample excitation was done by an intensity-modulated (0-200 mW) non-polarized Nd:YAG solid state laser with a wavelength of $532 \mathrm{~nm}$. The spectrometer was connected through fiber optics to a B\&W Tek microscope with a 20X objective (Microbeam S. A.), which gives a spot size of $105 \mu \mathrm{m}$. When using a 1200 grooves/mm diffraction grating and $198 \mu \mathrm{m}$ aperture of slit entrance, the resolution is better than $5 \mathrm{~cm}^{-1}$.

Bulk organic geochemistry. Stable isotopic composition of total nitrogen $\left(\delta^{15} \mathrm{~N}\right)$ and organic carbon $\left(\delta^{13} \mathrm{C}\right)$ was measured by Isotope-Ratio Mass Spectrometry (IRMS), using a MAT 253 (Thermo Fisher Scientific) and applying the USGS methods ${ }^{52}$, as described elsewhere ${ }^{53}$. Briefly, the homogenized, grounded samples were decarbonated with $\mathrm{HCl}$ and then dried $\left(50^{\circ} \mathrm{C}\right)$ after adjustment to neutral $\mathrm{pH}$ until constant weight. An analytical precision of $0.1 \%$ was determined by using three certified standards for carbon/nitrogen (USGS41, IAEA-600 and USGS40). The content of total nitrogen (TN) and organic carbon (TOC) was measured with an elemental analyzer (Flash HT, Thermo Fisher Scientific) during the stable isotope measurements. 
Molecular and isotopic lipid analysis. The lyophilized samples were extracted with a mixture of DCM:MeOH (3:1, v/v) to obtain a total lipid extract (TLE) by (i) ultrasonic bath (3x; further details in $\left.{ }^{54}\right)$ the MAT samples (1-3 g dw), or (ii) Soxhlet extraction $\left(24 \mathrm{~h}\right.$; details $\left.\mathrm{in}^{55}\right)$ the rest of samples $(\sim 30 \mathrm{~g} \mathrm{dw})$. In all cases, internal standards (tetracosane-D50, myristic acid-D27, 2-hexadecanol) were added prior to extraction. The clean, concentrated and desulphurized $\mathrm{TLE}^{54}$ was hydrolyzed overnight with $\mathrm{KOH}(6 \% \mathrm{MeOH})$ at room temperature ${ }^{56} . n$-Hexane was added to the hydrolyzed TLE to obtain the neutral fraction through liquid-liquid extraction. The remaining lipidic extract was then acidified with $\mathrm{HCl}(37 \%)$ to remove $\mathrm{K}^{+}$from the solution by precipitation of $\mathrm{KCl}$, then recovering the liberated carboxylic groups by liquid-liquid extraction with $n$-hexane (acidic fraction). Further separation of the neutral fraction into non-polar (hydrocarbons) and polar (alkanols and sterols) was done according to a method extensively described elsewhere ${ }^{55}$. Aliquots of the acidic fraction were heated with $1 \mathrm{ml}$ of $10 \% \mathrm{BF}_{3}$ in $\mathrm{MeOH}$ at $80^{\circ} \mathrm{C}$ for 30 min to methylate the fatty acids. Milli-Q water was then added and the products extracted with DCM (3x). Aliquots of the polar fraction were heated with $100 \mu \mathrm{l}$ of $\mathrm{N}, \mathrm{O}$-bis(trimethylsilyl)fluoroacetamide (BSTFA) at $80^{\circ} \mathrm{C}$ for $60 \mathrm{~min}$ to silylate the alcohols. Compounds in the apolar fraction (alkanes, alkenes and methyl alkanes) did not need of derivatization to be analyzed. All fractions were analyzed using gas chromatography-mass spectrometry (GC-MS) and isotope-ratio mass spectrometry system (IRMS) to determine the distribution and stable carbon isotopic composition of lipids (see ${ }^{41}$ for instrumental details). The identification of compounds was based on the comparison of mass spectra and/or reference materials on mass-to-charge ratios of 57 ( $n$-alkanes and isoprenoids), $m / z=74$ ( $n$-fatty acids as fatty acids methyl esters or FAMEs), and $m / z=75$ ( $n$-alkanols and sterols). For quantification, we used external calibration curves of $n$-alkanes (C10 to C40), $n$-FAME (C8 to C24), $n$-alkanols (C10, C14, C18, and C20), and branched isoprenoids (pristane, phytane, squalane, and squalene), all from Sigma Aldrich. Recovery of the internal standards was measured to average $70 \pm 21 \%$.

Statistical analysis. A principal component analysis (PCA) was performed with the software CANOCO5 v.5.12 (Microcomputer Power, Ithaca, NY) to understand the compositional variability of the hydrothermal samples (Text S7). For that, the distribution of nine variables was tested; biomass content (i.e., TOC), stable carbon isotopic composition of biomass $\left(\delta^{13} \mathrm{C}\right)$, and individual lipid biomarkers of bacteria, cyanobacteria, PhSnSB, $\mathrm{SRB}$, archaea, and thermophiles. A second analysis based on Redundancy Analysis (RDA) was performed to assess the influence of selected environmental variables ( $\mathrm{pH}$, water, and temperature) on the microbial composition of the samples. In both PCA and RDA, the variables were centered and standardized prior to the analysis.

Received: 15 September 2020; Accepted: 23 November 2020

Published online: 03 December 2020

\section{References}

1. Squyres, S. W. et al. Detection of silica-rich deposits on Mars. Science 320, 1063-1067 (2008).

2. Grotzinger, J. P. et al. A habitable fluvio-lacustrine environment at Yellowknife Bay, Gale Crater, Mars. Science 343, 1242777 (2014).

3. Cady, S.L. \& Farmer, J.D. Fossilization processes in siliceous thermal springs trends in preservation along thermal gradient, In Evolution of hydrothermal ecosystem on Earth (and Mars?). Ciba Foundation, 150-172 (Wiley, Hoboken, 1996).

4. Toporski, J. K. W., Steele, A., Westall, F., Thomas-Keprta, K. L. \& McKay, D. S. The simulated silicification of bacteria-new clues to the modes and timing of bacterial preservation and implications for the search for extraterrestrial microfossils. Astrobiology 2, $1-26$ (2002).

5. El-Maarry, M. R., Black, S. R., Hynek, B. M. \& McHenry, L. J. Mineralogy of fumarolic deposits from iceland as analogs for ancient hydrothermal systems on mars: role of temperature. Lunar Planet. Sci. Conf. 1964, 2870 (2017).

6. McHenry, L. J., Carson, G. L., Dixon, D. T. \& Vickery, C. L. Secondary minerals associated with lassen fumaroles and hot springs: implications for martian hydrothermal deposits. Am. Mineral. 102, 1418-1434 (2017).

7. Costello, L. J. et al. Habitability of hydrothermal systems at Jezero and Gusev craters as constrained by hydrothermal alteration of a terrestrial mafic dike. Geochemistry 80, 125613 (2020).

8. Bridges, J. C. \& Schwenzer, S. P. The nakhlite hydrothermal brine on Mars. Earth Planet. Sc. Lett. 359-360, 117-123 (2012).

9. Osinski, G. R. et al. Impact-generated hydrothermal systems on Earth and Mars. Icarus 224, 347-363 (2013).

10. Yen, A. S. et al. Hydrothermal processes at Gusev Crater: an evaluation of paso robles class soils. J. Geophys. Res-Planet. https:// doi.org/10.1029/2007JE002978 (2008).

11. Freissinet, C. et al. Organic molecules in the Sheepbed Mudstone, Gale Crater, Mars. J. Geophys Res. Planet 120, 495-514 (2015).

12. Eigenbrode, J. L. et al. Organic matter preserved in 3-billion-year-old mudstones at Gale crater, Mars. Planet. Sci. 360, 1096-1101 (2020).

13. Black, S. R. \& Hynek, B. M. Characterization of terrestrial hydrothermal alteration products with mars analog instrumentation: implications for current and future rover investigations. Icarus 307, 235-259 (2018).

14. Craddock, R. A. \& Greeley, R. Minimum estimates of the amount and timing of gases released into the martian atmosphere from volcanic eruptions. Icarus 204, 512-526 (2009).

15. McSween, H. Y., Taylor, J. \& Wyatt, M. B. Elemental composition of the Martian curst. Science 324, 736-739 (2009).

16. Tarnas, J. D. et al. Orbital indentification of hydrated silica in Jezero Crater, Mars. Geophys. Res. Lett. 46, 12771-12782 (2019).

17. Ruff, S. W., Campbell, K. A., Van Kranendonk, M. J., Rice, M. S. \& Farmer, J. The case for ancient hot springs in Gusev Crater. Mars. Astrobiology https://doi.org/10.1089/ast.2019.2044 (2020).

18. Carson, G. L., McHenry, L. J., Hynek, B. M., Cameron, B. I. \& Glenister, C. T. Leaching, precipitation, and oxidation in an icelandic hydrothermal system: comparison to Columbia Hills, Mars. Lunar Planet. Sci. Conf. 2132, 2209 (2019).

19. Warner, N. H. \& Farmer, J. D. Subglacial hydrothermal alteration minerals in Jökulhlaup Deposits of Southern Iceland, with implications for detecting past or present habitable environments on Mars. Astrobiology 10, 523-547 (2010).

20. Markússon, S. H. \& Stefánsson, A. Geothermal surface alteration of basalts, Krýsuvík Iceland-Alteration mineralogy, water chemistry and the effects of acid supply on the alteration process. J. Volcanol. Geoth. Res. 206, 46-59 (2011).

21. Mínguez, H. A., Ortega, L., Lunar, R., Martinez-Frías, J. \& Piña, R. Mineralogy of the hydrothermal alteration in the Námafjall geotermal field (Iceland). Revista de la Sociedad Española de Mineralogía 15, 25-26 (2011). 
22. Skirnisdottir, S. et al. influence of sulfide and temperature on species composition and community structure of hot spring microbial mats. Appl. Environ. Microb. 66, 2835-2841 (2000).

23. Tobler, D. J. \& Benning, L. G. Bacterial diversity in five Icelandic geothermal waters: temperature and sinter growth rate effects. Extremophiles 15, 473-485 (2011).

24. Robinson, N. \& Eglinton, G. Lipid chemistry of Icelandic hot spring microbial mats. Org. Geochem. 15, 291-298 (1990).

25. Van der Meer, M. T. J., Lammerts, L., Skirnisdottir, S., Sinninghe Damsté, J. S. \& Schouten, S. Distribution and isotopic coposition of bacterial lipid biomarkers in microbial mats from a sulfidic Icelandic hot spring. Org. Geochem. 39, 1015-1019 (2008).

26. Williams, A. J. et al. Fatty acid preservation in modern and relict hot-spring deposits in Iceland, with implications for organic detection on Mars. Astrobiology https://doi.org/10.1089/ast.2019.2115 (2021).

27. White, D. C., Pinkart, H. C. \& Ringelberg, A. B. Biomass measurements: biochemical approaches. In Manual of Environmental Microbiology (Eds. Hurst, C. J. et al.) 91-101 (ASM Press, Washington, 1997).

28. Jørgensen, B. B. \& Nelson, D. C. Bacterial zonation, photosynthesis, and spectral light distribution in hot spring microbial mats of Iceland. Microb. Ecol. 16, 133-147 (1988).

29. Van der Meer, M. T. J., Schouten, S., de Leeuw, J. W. \& Ward, D. W. Autotrophy of green non-sulfur bacteria in hot spring microbial mats: biological explanations for isotopically heavy organic carbon in the geological record. Environ. Microbiol. 2, 428-435 (2000).

30. Hayes, J.M. Fractionation of the isotopes of carbon and hydrogen in biosynthetic processes. National Meeting of the Geological Society of America, Boston, MA (2001).

31. Van der Meer, M. T. J. et al. Biosynthetic controls on the ${ }^{13} \mathrm{C}$ contents of organic components in the photoautotrophic bacterium Chloroflexus aurantiacus. J. Biol. Chem. 276, 10971-10976 (2001).

32. Ward, D. M., Ferris, M. J., Nold, S. C. \& Bateson, M. M. A natural view of microbial biodiversity within hot spring cyanobacterial mat communities. Microbiol. Mol. Biol. Rev. 62, 1353-1370 (1998).

33. Vestal, J. R. \& White, D. C. Lipid analysis in microbial ecology: quantitative approaches to the study of microbial communities. Bioscience 39, 535-541 (1989).

34. Langworthy, T. A., Holzer, G., Zeikus, J. G. \& Tornabene, T. G. Iso- and anteiso-branched glycerol diethers of the thermophilic anaerobe Thermodesulfotobacterium commune. Syst. Appl. Micrbiol. 4, 1-17 (1983).

35. Dowling, N. J. E., Widdel, F. \& White, D. C. Phospholipid ester-linked fatty acid biomarkers of acetate-oxidizing sulfatereducing bacteria and other sulfide-forming bacteria. J. Gen. Microbiol. 132, 1815-1825 (1986).

36. Hügler, M. \& Sievert, S. M. Beyond the Calvin Cycle: autotrophic carbon fixation in the ocean. Annu. Rev. Mar. Sci. 3, 261-289 (2011).

37. Cirés, S., Casero, M. C. \& Quesada, A. Toxicity at the edge of life: a review of cyanobacterial toxins from extreme environments. Mar. Drugs https://doi.org/10.3390/md15070233 (2017).

38. Fournier, R. O. Geochemistry and dynamics of the Yellowstone National Park Hydrothermal System. Annu. Rev. Earth Planet. Sci. 177, 13-53 (1989).

39. Lezcano, M. A. et al. Biomarker profiling of microbial mats in the geothermal band of Cerro Caliente, Deception Island (Antarctica): life at the edge of heat and cold. Astrobiology 19, 1490-1504 (2019).

40. Lynne, B. Y. Impact of three common post-depositional environmental settings on siliceous sinter diagenesis: an eight year experiment. J. Volcanol. Geotherm. Res. 292, 84-101 (2015).

41. Sánchez-García, L. et al. Microbial biomarker transition in high-altitude sinter mounds from El Tatio (Chile) through different stages of hydrothermal activity. Front. Microbiol. 9, 3350 (2019).

42. Kilias, S., Chatzitheodoridis, E. \& Lyon, I. Molecular, chemical and morphological evidence for hematite biogenicity at the Quaternary Cape Vani Mn-(Ba-Fe) deposit, Milos, Greece. Bull. Geol. Soc. Greece 47, 834-842 (2013).

43. Ferreira, G. M. \& Lobo, L. Q. The low-pressure phase diagram of sulfur. J. Chem. Thermodyn. 43, 95-104 (2011).

44. Eder, S. H., Gigler, A. M., Hanzlik, M. \& Winklhofer, M. Sub-micrometer-scale mapping of magnetite crystals and sulfur globules in magnetotactic bacteria using confocal Raman micro-spectrometry. PLoS ONE 9, e107356 (2014).

45. Eckert, B. \& Steudel, R. Molecular spectra of sulfur molecules and solid sulfur allotropes. In Elemental Sulfur und Sulfur-Rich Compounds II. Topics in Current Chemistry Vol. 231 (ed. Steudel, R.) (Springer, Berlin, 2003).

46. Poborchii, V. V. Raman spectra of sulfur, selenium or tellurium clusters confined in nano-cavities of zeolite A. Solid State Commun. 107, 513-518 (1998).

47. McHenry, L. J. et al. Secondary minerals associated with lassen fumaroles and hot springs: implications for Martian hydrothermal deposits. Am. Miner. 102, 1418-1434 (2017).

48. Squyres, S. W. et al. Pyroclastic activity at home plate in Gusev Crater, Mars. Science 316, 738-742 (2007).

49. Damer, B. \& Deamer, D. The hot spring hypothesis for an origin of life. Astrobiology https://doi.org/10.1089/ast.2019.2045 (2019).

50. Zakharova, O. K. \& Spichak, V. V. Geoghermal fields of Hengill volcano, Iceland. J. Volcanol. Seismol. 6, 1-14 (2012).

51. Kaasalainen, H. \& Stefánsson, A. Sulfur speciation in natural hydrothermal waters, Iceland. Geochim. Cosmochim. Ac. 75, $2777-$ 2791 (2011).

52. Révész, K., Qi, H. \& Coplen, T. B. Determination of the $\delta^{15} \mathrm{~N}$ and $\delta^{13} \mathrm{C}$ of total nitrogen and carbon in solids. RSIL lab code 1832, chap. 5 of Stable isotope-ratio methods. In Methods of the Reston Stable Isotope Laboratory (slightly revised from version 1.1 released in 2007) (Eds. Révész, C. \& Coplen, T. B., 2012).

53. Carrizo, D., Sánchez-García, L., Menes, R. J. \& García-Rodríguez, F. Discriminating sources and preservation of organic matter in surface sediments from five Antartic lakes in the Fildes Peninsula (King George Island) by lipid biomarkers and compoundspecific isotopic analysis. Sci. Total Environ. 672, 657-668 (2019).

54. Sánchez-García, L. et al. Molecular biomarkers in the subsurface of the Salar Grande (Atacama, Chile) evaporitic deposits. Biogeochemistry 144, 31-52 (2018).

55. Sánchez-García, L. et al. Simulating Mars drilling mission for searching for life ground-truthing lipids and other complex microbial biomarkers in the iron-sulfur rich Rio Tinto analog. Astrobiology https://doi.org/10.1089/ast.2019.2101 (2020).

56. Grimalt, J. O., Wit, R. D., Teixidor, P. \& Albaigès, J. Lipid biogeochemistry of Phormidium and Microcoleus mats. Org. Geochem. 19, 509-530 (1992).

57. Chen, L. et al. Molecular records of microbialites following the end-Permian mass extinction in Chongyang, Hubei Province, South China. Palaeogeogr. Palaeocl. 308, 151-159 (2011).

58. Zelles, L. Fatty acid patterns of phospholipids and lipopolysaccharides in the characterization of microbial communities in soil: a review. Biol. Fert. Soils 29, 111-129 (1999).

59. Gelpi, E., Scheider, H., Mann, J. \& Oro, J. Hydrocarbons of geochemical significance in microscopic algae. Phytochemistry 9 , 603-612 (1970).

60. Shiea, J., Brassell, S. C. \& Ward, D. M. Mid-chain branched mono- and dimethyl alkanes in hot spring cyanobacterial mats: a direct biogenic source for branched alkanes in ancient sediments. Org. Geochem. 15, 223-231 (1990).

61. Kenig, F. et al. Structure and distribution of branched aliphatic alkanes with quaternary carbon atoms in Cenomanian and Turonian black shales of Pasquia Hills (Saskatchewan, Canada). Org. Geochem. 36, 117-138 (2005).

62. Allen, M. A., Neilan, B. A., Burns, B. P., Jahnke, L. L. \& Summons, R. E. Lipid biomarkers in Hamelin Pool microbial mats and stromatolites. Org. Geochem. 41, 1207-1218 (2010).

63. Sakata, S. et al. Carbon isotopic fractionation associated with lipid biosynthesis by a cyanobacterium: relevance for interpretation of biomarker records. Geochim. Cosmochim. Ac. 61, 5379-5389 (1997). 
64. Ahlgren, G., Gustafsson, I.-B. \& Boberg, M. Fatty acid content and chemical composition of freshwater microalgae. J. Phicol. 28, 37-50 (1992).

65. Pagès, A. et al. Lipid biomarker and isotopic study of community distribution and biomarker preservation in a laminated microbial mat from shark bay, Western Australia. Microb. Ecol. 70, 459-472 (2015).

66. Fang, J. et al. Biomarker analysis of microbial diversity in sediments of a saline groundwater seep of Salt Basin, Nebraska. Org. Geochem. 37, 912-931 (2006).

67. Grossi, V. et al. Biotransformation pathways of phytol in recent anoxic sediments. Org. Geochem. 29, 845-861 (1998).

68. Londry, K. L. \& Des Marais, D. J. Stable carbon isotope fractionation by sulfate-reducing bacteria. Appl. Environ. Microbiol. 69, 2942-2949 (2004).

69. Konneke, M. \& Widdel, F. Effect of growth temperature on cellular fatty acids in sulphate-reducing bacteria. Environ. Microbiol. 5, 1063-1070 (2003).

70. Tornabene, T. G., Langworthy, T. A., Holzer, G. \& Oro, J. Squalenes, phytanes and other isoprenoids as major neutral lipids of methanogenic and thermoacidophilic archaebacteria. J. Mol. Evol. 13, 73-83 (1979).

71. Stiehl, T., Rullkötter, J. \& Nissenbaum, A. Molecular and isotopic characterization of lipids in cultured halophilic microorganisms from the Dead Sea and comparison with the sediment record of this hypersaline lake. Org. Geochem. 36, 1242-1251 (2005).

72. Carballeira, N. M. et al. Unusual fatty acid compositions of the hyperthermophilic archaeon Pyrococcus furiosus and the bacterium Thermotoga maritima. J. Bacteriol. 179, 2766-2768 (1997).

73. Gall, A., Pascal, A. A. \& Robert, B. Vibrational techniques applied to photosynthesis: resonance Raman and fluorescence linenarrowing. BBA-Bioenergetics 1847, 12-18 (2015).

\section{Acknowledgements}

This work is the result of the research and field campaign funded by two Europlanet projects with Grant Agreement Nos. 17-EPN3-004 and 16-EPN2-064. The authors thank Viggó Pór Marteinsson and Rene Groben from Matís (Reykjavik, Iceland) for their formation and logistics assistance during the field campaign. This work was funded by the Spanish Ministry of Science and Innovation and Fondo Europeo de Desarrollo Regional (MICINN/FEDER) Grants No. RYC-2014-19446 (L.S.-G.); RYC2018-023943-I (D.C.); ERC CoG no. 818602 (A.M.); ESP2017-89053-C2-1-P (V.M.-I. and O.P.-B.); FJC2018-037246-I (M.A.L.); RTI2018-094368-B-I00 (V.P.); and the Spanish State Research Agency (AEI) Grant No. MDM-2017-0737 Unidad de Excelencia "María de Maeztu"-Centro de Astrobiología (CSIC-INTA).

\section{Author contributions}

L.S.-G., D.C., and A.M. collected the samples and designed the study. L.S.-G. and D.C. conducted the biomarkers analysis and their interpretation. L.S-G. wrote the paper. V.M.-I. carried out the Raman analysis, interpreted the spectral data, and built Fig. 5. O.P-B. and M.T.F.-S. conducted and interpreted the XRD and FTIR analysis. O.P-B. and A.M. built Fig. 6 and interpreted the sites mineralogy and geochemistry in a Martian context. M.A.L. conducted and interpreted the statistical analysis. V.P. contributed to write the manuscript.

\section{Competing interests}

The authors declare no competing interests.

\section{Additional information}

Supplementary information is available for this paper at https://doi.org/10.1038/s41598-020-78240-2.

Correspondence and requests for materials should be addressed to L.S.-G.

Reprints and permissions information is available at www.nature.com/reprints.

Publisher's note Springer Nature remains neutral with regard to jurisdictional claims in published maps and institutional affiliations.

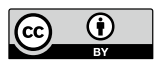

Open Access This article is licensed under a Creative Commons Attribution 4.0 International License, which permits use, sharing, adaptation, distribution and reproduction in any medium or format, as long as you give appropriate credit to the original author(s) and the source, provide a link to the Creative Commons licence, and indicate if changes were made. The images or other third party material in this article are included in the article's Creative Commons licence, unless indicated otherwise in a credit line to the material. If material is not included in the article's Creative Commons licence and your intended use is not permitted by statutory regulation or exceeds the permitted use, you will need to obtain permission directly from the copyright holder. To view a copy of this licence, visit http://creativecommons.org/licenses/by/4.0/.

(C) The Author(s) 2020 